\title{
IMPROVING THE TECHNIQUE OF SCRAMBLED DESSERTS USING THE FOOD SUPPLEMENT "MAGNETOFOOD"
}

\author{
Iryna Tsykhanovska \\ Department of food and chemical technologies \\ Ukrainian Engineering-Pedagogics Academy \\ 16 Universitetska str., Kharkiv, Ukraine, 61003 \\ cikhanovskaja@gmail.com
}

Victoria Yevlash

Department of Chemistry, Microbiology and Food Hygiene

Kharkiv State University of Nutrition and Trade

333 Klochkivska str., Kharkiv, Ukraine, 61051

evlashvv@gmail.com

Alexandr Alexandrov

Department of food and chemical technologies

Ukrainian Engineering-Pedagogics Academy

16 Universitetska str., Kharkiv, Ukraine, 61003

alexandrov.a.v.a.v@gmail.com

Barna Khamitova

Department of Technology and Food Safety

M. Auezov South-Kazakhstan State University

5 Taukekhan ave., Shymkent, Kazakhstan, 160012

barno-007@mail.ru

\section{Karyna Svidlo}

Department of Technology and Restaurant Business Organization

Kharkiv Trade and Economic Institute of

Kyiv National Trade and Economic University of Ukraine

8 O. Yarosha lane, Kharkiv, Ukraine, 61045

karinasvidlo@gmail.com

\section{Olesia Nechuiviter}

Department of Information Computer and Printing Technologies

Ukrainian Engineering-Pedagogics Academy

16 Universitetska str., Kharkiv, Ukraine, 61003

olesia.nechuiviter@gmail.com

\footnotetext{
Abstract

For improving the technology of scrambled dessert products, a food supplement, based on the nanopowder of oxides of two- and trivalent iron "Magnetofood" was introduced in the recipe composition. The object of the studies is base recipes: one of mousse "Cranberry" and sambuk "Apple". For determining technological characteristics and quality parameters, conventional standard methods were used.

It has been established, that introduction of the food supplement "Magnetofood" in amount $0,1 \%, 0,15 \%, 0,2 \%$ of the recipe mixture mass improves consumption properties of scrambled desserts. The mean value of the organoleptic analysis increases by $(1,25 \pm 0,1)$ points. The density also decreases by $(29 \pm 1) \mathrm{kg} / \mathrm{m}^{3}$ for mousses, by $(26 \pm 1) \mathrm{kg} / \mathrm{m}^{3}$ for sambuks, and scrambling duration - by $\sim 3$ minutes. At storing during 24 hours at $\eta=(90 \pm 2) \%$, the microbial contamination of the surface of samples decreases QMAFAnM in 10 times, yeasts - in 2 times, molds - in 2 times.

It has been established, that introduction of the supplement "Magnetofood" favors the growth of the foam-creating ability in average: by $(40 \pm 2) \%$ for mousses, by $(55 \pm 3) \%$ for sambuks. The porosity increases by $(14,3 \pm 0,7) \%$ for mousses, by $(12,7 \pm 0,6) \%$ for sambuks. The foam structure stability of scrambled desserts improves by $(14 \pm 1,1) \%$. The food supplement "Magnetofood" also raises the effective viscosity by $(32 \pm 1) \mathrm{Pa} \cdot s$ for mousses and by $(41 \pm 2) \mathrm{Pa} \cdot \mathrm{s}$ for sambuks and the mechanical strength of scrambled
} 
desserts in 1,23 times.

The highest parameters were inherited to mousses and sambuks with supplement "Magnetofood" mass share $0,15 \%$.

There have been experimentally substantiated scrambling technological parameters and regimes of recipe mixtures of berry-fruit mousses and sambuks, modified by the food supplement "Magnetofood". The total scrambling duration is (14-16) minutes. The initial scrambling speed of the berry-fruit base is $(2,0-2,2) \mathrm{s}^{-1}$, at that the scrambling time is $(5-6) \cdot 60 \mathrm{~s}$. Then the recipe mixture is scrambled at speed $(3,3-3,5) \mathrm{s}^{-1}$ during (3-4) $60 \mathrm{~s}$. Scrambling is finished at speed $(2,0-2,2) \mathrm{s}^{-1}$. The distinctive feature of the improved technology is premixing of the food supplement "Magnetofood" with gelatin, realized before the technological operation of soaking gelatin in cold water.

The obtained experimental data may be used at developing innovative technologies of scrambled dessert products with the food supplement "Magnetofood".

Keywords: food supplement "Magnetofood", berry-fruit mousses and sambuks, functional-technological, structural-mechanical properties, quality and safety parameters.

\section{Introduction}

In a situation, formed in production of scrambled desserts, namely the deficit of raw materials in Ukraine, high prices for the essential share of import ingredients and so on, scientists are searching for ways for increasing the competitiveness of ready products at the expanse of improving and stabilizing the quality, decreasing the cost price and prolonging storage terms [1-3].

For widening the assortment of scrambled dessert products and improving their consumption properties, different arrangements are used. There are used new raw material components that give a possibility to change or correct:

- functional-technological properties of foam structures;

- texture, consistence, quality parameters;

- storage terms [1, 4-6].

For improving properties of foam structures of scrambled desserts, there are used different foam-creators of the protein nature: whey protein gels - for foam stabilization [7]; proteins-hydrophobins - as new functional ingredients with high foam-creating and stabilizing abilities [8]; compound protein micelles of surfactant with caseinate - functional ingredients with high stabilizing and structure-creating effects [9]; protein complex of casein and whey proteins with polysaccharides (cellulose, ethyl cellulose, hydrophobically-modified starch granules) - with a high foam-creating, emulsifying and stabilizing effect [10]; complexes of fish gelatin (FG) with alginate (AL) - for improving the foam creation and foam stability of scrambled desserts [11].

Some scientists developed combined systems of structure-creators, especially ones of gelatin with pectin, with sulphate polysaccharides; gelatin - k-carrageenan, gelatin-LM pectin for regulating structural-mechanical properties of foam structures [12].

Today binary mixtures of biopolymers are widely used for increasing the stability of foam structures. They consist of protein and one polysaccharide ( $\beta$-lactoglobulin + Arabian gum; $\beta$-lactoglobulin + pullulan; whey protein isolate + Arabian gum; egg protein albumin + pectin and so on) $[26,27]$. For stabilizing scrambled dessert products, there is offered to use raw materials, obtained from grain crops (oats, barley, soya) [28, 29], and also food supplements of the vegetable origin: medical and spicy-aromatic herbs as powders or extracts, vegetable and berry-fruit powders [30]. For increasing the foam-creating ability of egg protein, it's added with different vegetable and fruit-berry purees, especially ones of feijoa, kiwi, artichokes and so on [24, 25]. But the foam structure stability grew insufficiently, and the system foam-creating ability decreased at the synchronously observed decrease of its viscosity.

For regulating structural-mechanical properties of foam structures, there begun to be used biological stabilizers [31] and nanosupplements (particles of modified silica) [32]. But data are insufficient and contradictory. The analysis of information sources [1, 10-32] demonstrates the absence of data about technologies of scrambled desserts with using nanopowder supplements with foam- and structure-creating, stabilizing properties. They also improve their structural-mechanical properties of foam 
structures, quality parameters and storage terms. The food supplement "Magnetofood" is offered as an improver for food systems. In food systems "Magnetofood" displays antioxidant, sorption, bacteriostatic, complex-creating, emulsifying, water-binding, stabilizing, structure-creating properties [7-9].

The aim of the research is to study the influence of the supplement "Magnetofood" on properties of scrambled desserts, especially mousses and sambuks, that allows to widen the assortment of scrambled dessert products of the improved quality with increased storage terms.

\section{Materials and Methods}

\section{1. Studied materials and equipment, used in the experiment}

The object of the research is the technology of berry-fruit mousses and sambuks.

The research subjects: experimental samples of berry-fruit mousses and sambuks on basic recipes: Mousse “Cranberry” № 898 and sambuk “Apple or plum” № 904 [21]:

- Sample 1 control (mousse "Cranberry");

- Sample 2 - mousse "Raspberry" with the food supplement "Magnetofood" in amount $0,10 \%$ of the recipe composition;

- Sample 3 - mousse "Raspberry" with the food supplement "Magnetofood" in amount $0,15 \%$ of the recipe composition;

- Sample 4 - mousse "Raspberry" with the food supplement "Magnetofood" in amount $0,20 \%$ of the recipe composition;

- Sample 5 control (sambuk "Apple");

- Sample 6-sambuk "Berry" with the food supplement "Magnetofood" in amount 0, $10 \%$ of the recipe composition;

- Sample 7 - sambuk "Berry" with the food supplement "Magnetofood" in amount 0, $15 \%$ of the recipe composition;

- Sample 8-sambuk "Berry" with the food supplement "Magnetofood" in amount 0, $20 \%$ of the recipe composition;

Fig. 1 presents the experimental samples of berry-fruit mousses and sambuks.

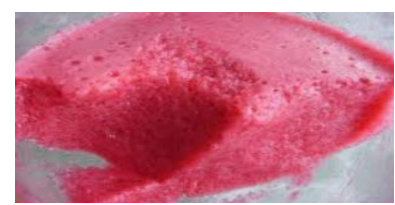

$a$

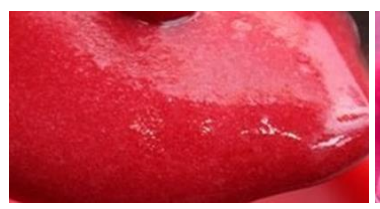

$c$

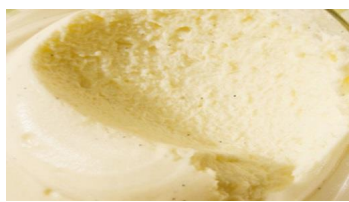

$e$

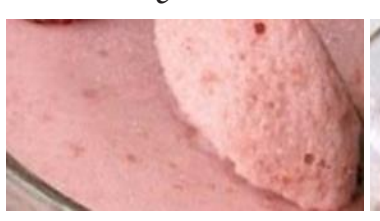

$g$

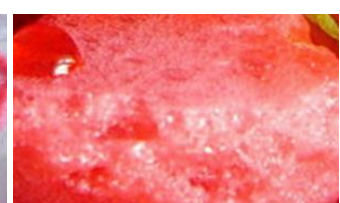

$b$

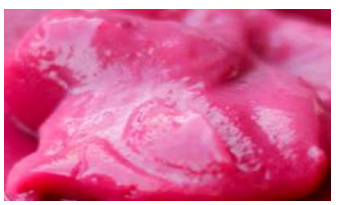

$d$

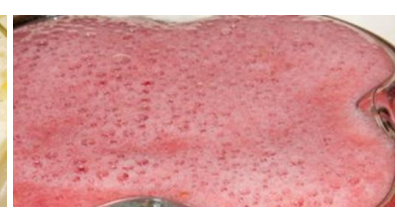

f

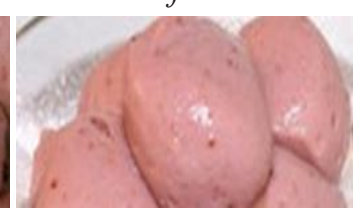

$h$

Fig. 1. Experimental samples of berry-fruit scrambled desserts: $a$ - sample $1 ; b$ - sample 2; $c$-sample $3 ; d-3$ sample $4 ; e$-sample $5 ; f$-sample $6 ; g$ - sample $7 ;$ h-sample 8 
Fig. 2 presents the devices, used for studying structural-mechanical properties of the experimental samples of mousses and sambuks. The density was determined by the Sosnovsky device (Russia); viscosity properties were determined using the rotation viscosimeter Reotest-2 (Germany); strength characteristics were determined on the penetrometer AP-4/1 (Russia). Microscopy of the samples was determined on the monocular microscope by BIOLAM LOMO (Russia).

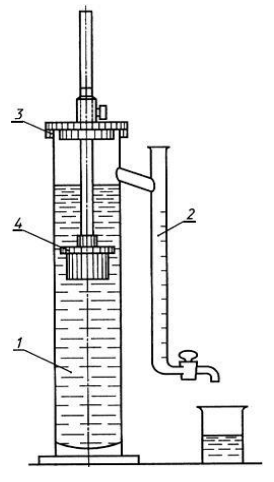

$a$

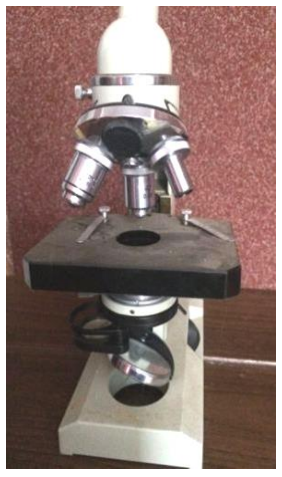

$b$

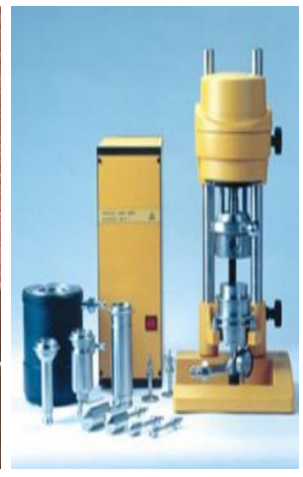

c

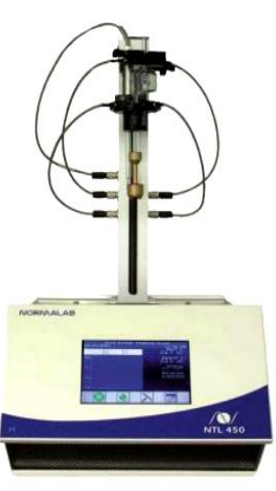

$d$

Fig. 2. Devices, used for studying parameters of mousses and sambuks: $a$ - Sosnovsky device; $b$ - monocular microscope by BIOLAM LOMO; $c$ - rotation viscosimeter Reotest-2; $d$ - penetrometer AP-4/1

\section{2. Method of determining functional-technological, structural-mechanical and mi-} crobiological parameters

In the experiment there were used standard and conventional research methods, considered below [22-26]. The foam-creating ability (FA) and foam stability (FS) were determined by Lurje and Rauch methods $[22,23]$. The density of mousses and sambuks was determined on Sosnovsky device [24]. Viscosity characteristics of the experimental samples of mousses and sambuks were determined on the rotation viscosimeter Reotest-2 according to instruction [25]. The determination of strength properties was realized on the penetrometer AP-4/1 by standard methodology $[23,26,27]$.

The dispersion and porosity were determined using monocular microscope BIOLAM LOMO $[22,23]$.

The list of microbiological parameters for controlling the quality of ready scrambled dessert products was established according to the requirements of SSU 4683:2006 and [28].

The organoleptic evaluation of the quality of ready scrambled desserts was realized by the method of sensor analysis by five-pint system [22, 29].

\section{Experimental procedures}

Table 1 presents the influence of the food supplement "Magnetofood" on structural-mechanical properties of the experimental samples of mousses and sambuks.

Table 1

Structural-mechanical properties of the experimental samples of mousses and sambuks with adding "Magnotofood" ( $=5, \mathrm{p} \leq 0,05)$

\begin{tabular}{|c|c|c|c|c|c|c|c|c|}
\hline \multirow{3}{*}{ Parameter name } & \multicolumn{8}{|c|}{ Experimental samples of scrambled desserts } \\
\hline & \multicolumn{4}{|c|}{ Experimental samples of mousse } & \multicolumn{4}{|c|}{ Experimental samples of sambuk } \\
\hline & Sample 1 & Sample 2 & Sample 3 & Sample 4 & Sample 5 & Sample 6 & Sample 7 & Sample 8 \\
\hline Density, $\mathrm{kg} / \mathrm{m}^{3}$ & $610 \pm 2$ & $585 \pm 2$ & $580 \pm 2$ & $578 \pm 2$ & $630 \pm 2$ & $595 \pm 2$ & $590 \pm 2$ & $588 \pm 2$ \\
\hline Porosity, \% & $44 \pm 0,5$ & $57 \pm 0,5$ & $59 \pm 0,5$ & $60 \pm 0,5$ & $41 \pm 0,5$ & $53 \pm 0,5$ & $55 \pm 0,5$ & $56 \pm 0,5$ \\
\hline Foam-creating ability, $\%$ & $220 \pm 2$ & $267 \pm 2$ & $287 \pm 3$ & $270 \pm 3$ & $268 \pm 2$ & $320 \pm 3$ & $350 \pm 3$ & $340 \pm 3$ \\
\hline Foam stability, $\%$ & $83 \pm 1$ & $90 \pm 1$ & $97 \pm 2$ & $95 \pm 2$ & $83 \pm 1$ & $89 \pm 1$ & $97 \pm 2$ & $95 \pm 2$ \\
\hline Strength, $\mathrm{R} \cdot 10^{3}, \mathrm{~kg}$ & $126 \pm 2$ & $140 \pm 2$ & $163 \pm 3$ & $161 \pm 3$ & $127 \pm 2$ & $159 \pm 2$ & $174 \pm 3$ & $172 \pm 3$ \\
\hline Effective viscosity, $\mathrm{Pa} \cdot \mathrm{s}$ & $661 \pm$ & $87 \pm 2$ & $97 \pm 2$ & $99 \pm 2$ & $79 \pm 1$ & $98 \pm 2$ & $108 \pm 2$ & $112 \pm 2$ \\
\hline
\end{tabular}


The data of Table 1 testify that the use of the food supplement "Magnetofood" improves the structural-mechanical parameters of the experimental samples of fruit-berry mousses and sambuks. Fig. 3 presents the organoleptic profiles of the experimental samples of the scrambled desserts with adding the food supplement "Magnetofood" comparing with the control samples.

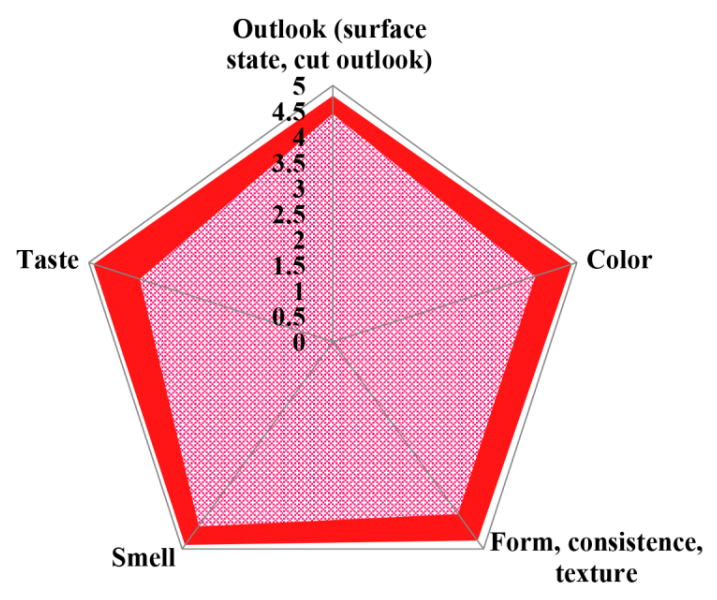

- Mousse "Raspberry" 웡 Mousse "Cranberry"

$a$

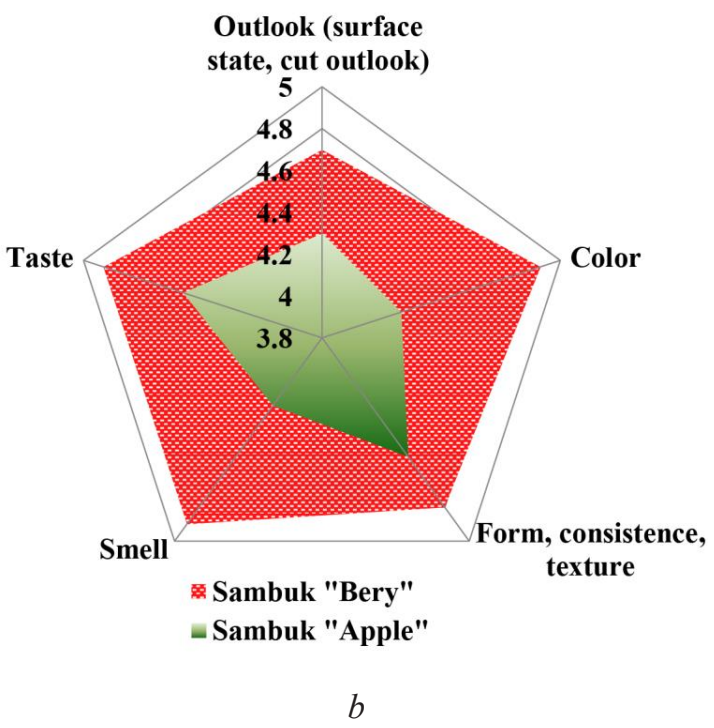

Fig. 3. Results of the organoleptic analysis of the experimental samples of the scrambled desserts with adding the food supplement "Magnetofood" comparing with the control samples: $a$ - sample $3 ; b$ - sample 7

The sensor evaluation results (Table 2, Fig. 3) demonstrate that the mean value of the point evaluation of the experimental samples by the organoleptic analysis increase by $(1,2-1,3)$ points comparing with the control.

Fig. 4 presents the technological scheme of mousse "Raspberry" adding the food supplement "Magnetofood" in rational amount $-0,15 \%$ of the recipe mixture mass (sample 3 ).

There were studied the quality microbiological parameters of the experimental samples of the scrambled desserts (Table 2).

The data of Table 2 testify that introduction of the food supplement "Magnetofood" decreases contamination of the surface of the experimental samples of the scrambled desserts. 


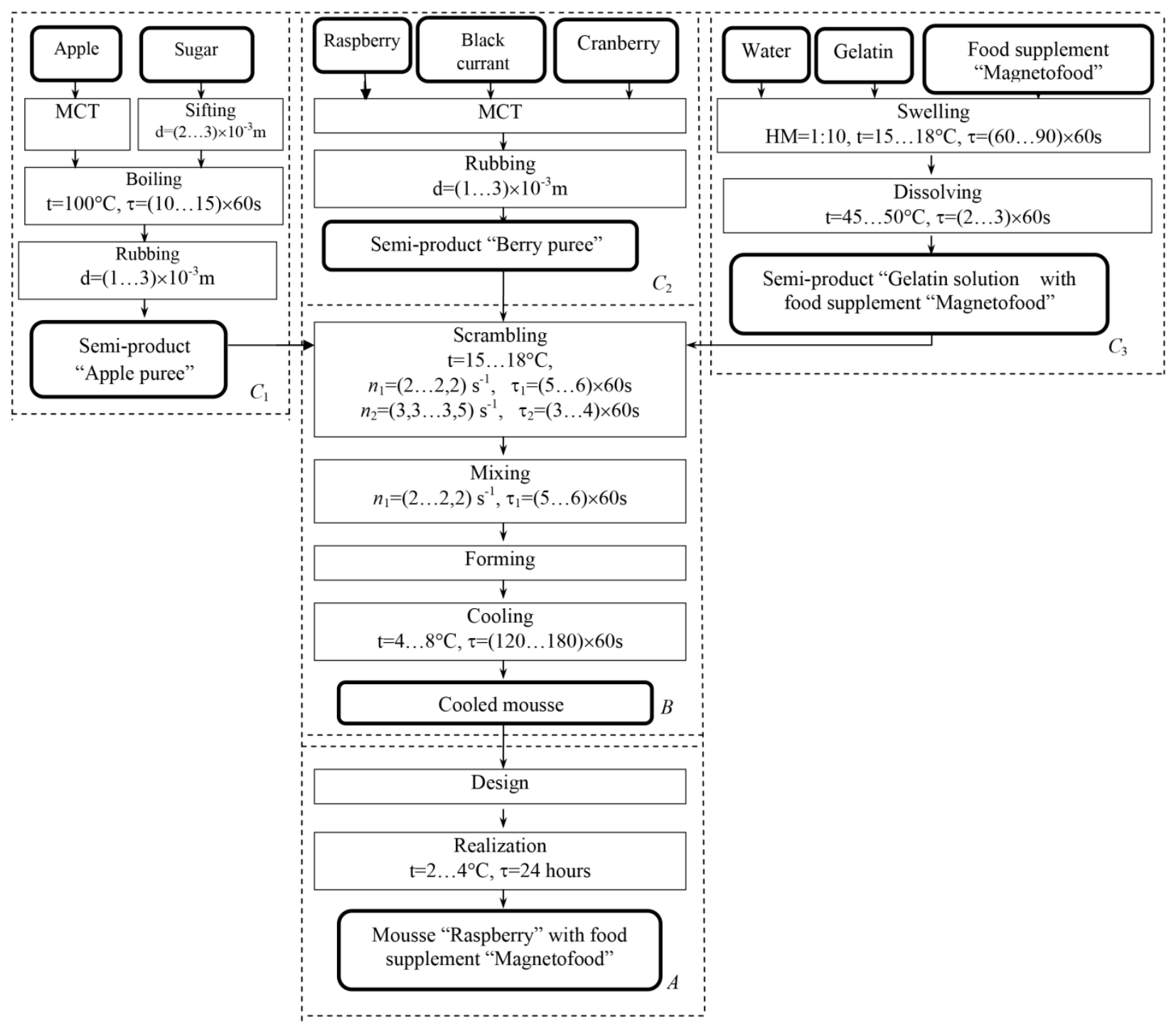

Fig. 4. Technological scheme of berry-fruit mousse "Raspberry" with adding $0,15 \%$ of the food supplement "Magnetofood": $\mathrm{A}, \mathrm{B}, \mathrm{C}_{1}, \mathrm{C}_{2}, \mathrm{C}_{3}$ - subsystems of the technological scheme of mousse production

Table 2

Microbiological parameters of the experimental samples of the scrambled desserts comparing with the control at storage

\begin{tabular}{|c|c|c|c|c|}
\hline \multirow{2}{*}{ Parameter name } & \multirow{2}{*}{ Standard } & \multicolumn{3}{|c|}{ Samples of scrambled desserts at $\varphi=(90 \pm 2) \%$} \\
\hline & & Control & Sample 3 & Sample 7 \\
\hline \multicolumn{5}{|c|}{ Storage term 24 hours } \\
\hline $\begin{array}{c}\text { QMAFAnM, CCU/g, } \\
\text { immediately-after } 24 \text { hours }\end{array}$ & $1,0 \times 10^{3}$ & $0,5 \times 10^{3} / 1,0 \times 10^{3}$ & $0,5 \times 10^{2} / 1,0 \times 10^{2}$ & $0,5 \times 10^{2} / 1,0 \times 10^{2}$ \\
\hline Yeasts, CCU/g, immediately-after 24 hours & 50 & $6,0 / 8,0$ & $3,0 / 4,0$ & $3,0 / 4,0$ \\
\hline $\begin{array}{l}\text { BCBG (coliforms), in } 1,0 \mathrm{~g} \text {, } \\
\text { immediately-after } 24 \text { hours }\end{array}$ & No dose & Not revealed & Not revealed & Not revealed \\
\hline $\begin{array}{l}\text { Pathogenic m/o, including bacteria of } \\
\text { Salmonella generis, in } 25 \mathrm{~g}, \\
\text { immediately-after } 24 \text { hours }\end{array}$ & No dose & Not revealed & Not revealed & Not revealed \\
\hline Molds, CCU/g, immediately-after 24 hours & 50 & $4,0 / 6,0$ & $2,0 / 3,0$ & $2,0 / 3,0$ \\
\hline
\end{tabular}




\section{Results}

It has been experimentally established (Table 1), that introduction of the food supplement "Magnetofood" in amount $(0,10 ; 0,15 ; 0,20) \%$ of the recipe composition favors the improvement of the properties of the scrambled desserts:

- the foam-creating ability increases by $(40 \pm 2) \%$ for mousses and by $(55 \pm 3) \%$ for sambuks, and the scrambling time decreases by $15 \%$;

- the foam stability increases by $(14 \pm 1,1) \%$ and the effective viscosity - by (32 \pm 1$) \mathrm{Pa} \cdot \mathrm{s}$ for mousses and by (41 \pm 2$) \mathrm{Pa} \cdot \mathrm{s}$ for sambuks, and also the mechanical strength - in 1,23 times;

- the porosity grows by $(14.3 \pm 0.7) \%$ for mousses and by $(12.7 \pm 0.6) \%$ for sambuks, the density decreases by $(29 \pm 1) \mathrm{kg} / \mathrm{m}^{3}$ for mousses and by $(26 \pm 1) \mathrm{kg} / \mathrm{m}^{3}$ for sambuks.

The organoleptic analysis of the quality of the experimental samples of the scrambled desserts (Fig. 3) testifies to the high quality and new consumption properties.

The technological process of scrambled desserts production (Fig. 4) includes the following subsystems:

1) Subsystem $\mathrm{C}$ - preparation of stuffs and materials for production that provides preparation of recipe mixture components.

$\mathrm{C}_{1}, \mathrm{C}_{2}$ - Obtaining of semi-products: "Apple puree" and "Berry puree" by baking apples at $\mathrm{t}=(160 \pm 5)^{\circ} \mathrm{C}$ during $\tau=(10-15) \cdot 60$ s with further rubbing through a sieve with orifices diameter $\mathrm{d}=(1-3) 10^{-3} \mathrm{~m}$. Raspberry, strawberry and cranberry are rubbed without baking (only cranberry is steamed);

$\mathrm{C}_{3}$ - Preparation of structure-creators. The semi-product "Gelatin solution with the food supplement "Magnetofood" is prepared. For that the dry mixture of gelatin with the food supplement "Magnetofood is kept in cold water at temperature $(15-18){ }^{\circ} \mathrm{C}$ during $\tau=(60-90) \cdot 60 \mathrm{~s}$. Then gelatin is dissolved and "Magnetofood" is solvated at temperature $45-50{ }^{\circ} \mathrm{C}$ during (2-3) $60 \mathrm{~s}$.

2) The subsystem B. Preparation of the product. The food mixture of mousse (sambuk) berry-fruit puree at temperature $(15-18){ }^{\circ} \mathrm{C}$ during (5-6) $60 \mathrm{~s}$ at scrambling speed $(2,0-2,2) \mathrm{s}^{-1}$. At the end - mixing of the composition during (5-6) $60 \mathrm{~s}$ at the speed $\mathrm{n}_{1}=(2,0-2,2) \mathrm{s}^{-1}$. Then formation, structure creation and cooling. The total duration of structure creation and cooling (120-180) $60 \mathrm{~s}$ at temperature $(4-8){ }^{\circ} \mathrm{C}$.

3) Subsystem A. Commodity design and realization. Ready products are formed and stored at temperature $(2-6){ }^{\circ} \mathrm{C}$ during 24 hours.

Introduction of the food supplement "Magnetofood" inhibits the development of microorganisms in the scrambled desserts (Table 2): at storage of the experimental samples of mousse "Raspberry" and sambuk "Berry" at air humidity $(90 \pm 2) \%$ during 24 hours, QMAFAnM decreases in 10 times, yeasts in 2 times, molds in 2 times in samples 3, 7 comparing with the control.

The obtained experimental data may be used at developing technologies of scrambled dessert products.

\section{Conclusions}

The methods of studying mousses and sambuks, presented in the work, may be used at investigating the influence of different supplements, improvers, stabilizers, stiffeners, structure-creators etc on technological characteristics of scrambled desserts.

A shortcoming of this work is the fact that only two types of scrambled desserts were considered - berry-fruit mousse and sambuk. It is unknown, how this supplement will influence technological parameters of scrambled desserts on other structure-creators (agar, pectin and so on).

A positive side is the fact, that the determined parameters of quality and safety of the berry-fruit scrambled desserts with adding the food supplement "Magnetofood" illustrate the essential improvement at the expanse of introducing the little amount of the improver. It gives a possibility to state that in food systems "Magnetofood" manifests antioxidant, sorption, bacteriostatic, complex-creating, emulsifying, water-binding, stabilizing, structure-creating properties.

The research methods, presented in the work, may be also used for studying quality parameters and functional-technological characteristics, especially organoleptic, microbiological, struc- 
tural-mechanical, of not only berry-fruit scrambled dessert semi-products and desserts, produced of them, but also milk, chocolate ones, on agar, pectin and so on.

At the same time the research results may be offered for the technological process of berry-fruit mousses and sambuks with adding the food supplement "Magnetofood".

\section{References}

[1] Horal'chuk, A. B. (2016). Naukove obgruntuvannya tekhnolohiy napivfabrykativ byvnykh dlya kulinarnoyi ta kondyters'koyi produktsiyi z polifaznoyu strukturoyu. Kharkiv: KhDUKhT, 42. 00129.html

[2] Kynin, A. Sozdanie "pustoty" v materialah. Available at: http://www.metodolog.ru/00129/

[3] Osipov, A. A. (2007). Primenenie zagustiteley i stabilizatorov pri proizvodstve dzhemov i drugih fruktovo-yagodnyh produktov. Pishchevaya promyshlennost', 4, 52-53.

[4] Mayurnikova, L. A., Latkov, N. Yu. (2004). Sozdanie molochnyh desertov profilakticheskogo naznacheniya. Hranenie i pererabotka sel'hozsyr'ya: Teoreticheskiy zhurnal, 3, 60-62.

[5] Dickinson, E. (2006). Interfacial Particles in Food Emulsions and Foams. Colloidal Particles at Liquid Interfaces, 298-327. doi: https://doi.org/10.1017/cbo9780511536670.009

[6] Percevoy, F. V. et. al. (2003). Proizvodstvo zheleynoy i vzbivnoy produkcii s ispol'zovaniem modifikatorov. Dnepr: Porogi, 201.

[7] Lazidis, A., Hancocks, R. D., Spyropoulos, F., Kreuß, M., Berrocal, R., Norton, I. T. (2016). Whey protein fluid gels for the stabilisation of foams. Food Hydrocolloids, 53, 209-217. doi: https://doi.org/ 10.1016/j.foodhyd.2015.02.022

[8] Green, A. J., Littlejohn, K. A., Hooley, P., Cox, P. W. (2013). Formation and stability of food foams and aerated emulsions: Hydrophobins as novel functional ingredients. Current Opinion in Colloid \& Interface Science, 18 (4), 292-301. doi: https://doi.org/10.1016/j.cocis.2013.04.008

[9] Dickinson, E. (2015). Structuring of colloidal particles at interfaces and the relationship to food emulsion and foam stability. Journal of Colloid and Interface Science, 449, 38-45. doi: https://doi.org/ 10.1016/j.jcis.2014.09.080

[10] Murray, B. S., Durga, K., Yusoff, A., Stoyanov, S. D. (2011). Stabilization of foams and emulsions by mixtures of surface active food-grade particles and proteins. Food Hydrocolloids, 25 (4), 627-638. doi: https://doi.org/10.1016/j.foodhyd.2010.07.025

[11] Phawaphuthanon, N., Yu, D., Ngamnikom, P., Shin, I.-S., Chung, D. (2019). Effect of fish gelatine-sodium alginate interactions on foam formation and stability. Food Hydrocolloids, 88, 119-126. doi: https://doi.org/10.1016/j.foodhyd.2018.09.041

[12] Foshchan, A. L., Hryhorenko, A. M. (2010). Rehuliuvannia reolohichnykh ta strukturno-mekhanichnikh vlastyvostei zheleinykh vyrobiv ta napivfabrykativ na osnovi kombinovanykh system drahle utvoriuvachiv. Khlibopekarska i kondyterska promyslovist Ukrainy, 2, 29-30.

[13] Fioramonti, S. A., Perez, A. A., Aríngoli, E. E., Rubiolo, A. C., Santiago, L. G. (2014). Design and characterization of soluble biopolymer complexes produced by electrostatic self-assembly of a whey protein isolate and sodium alginate. Food Hydrocolloids, 35, 129-136. doi: https://doi.org/10.1016/j.foodhyd.2013.05.001

[14] Mao, L., Boiteux, L., Roos, Y. H., Miao, S. (2014). Evaluation of volatile characteristics in whey protein isolate-pectin mixed layer emulsions under different environmental conditions. Food Hydrocolloids, 41, 79-85. doi: https://doi.org/10.1016/j.foodhyd.2014.03.025

[15] Wang, M.-P., Chen, X.-W., Guo, J., Yang, J., Wang, J.-M., Yang, X.-Q. (2019). Stabilization of foam and emulsion by subcritical water-treated soy protein: Effect of aggregation state. Food Hydrocolloids, 87, 619-628. doi: https://doi.org/10.1016/j.foodhyd.2018.08.047

[16] Iorgacheva, E. G., Iorgacheva, E. G., Banova, S. I. (2002). Modificirovannye soeprodukty suluchshennymi penoobrazuyushchimi i emul'giruyushchimi svoystvami. Zernovi produkty i kombikormy, 2, 23-25.

[17] Burgos-Díaz, C., Wandersleben, T., Olivos, M., Lichtin, N., Bustamante, M., Solans, C. (2019). Food-grade Pickering stabilizers obtained from a protein-rich lupin cultivar (AluProt-CGNA $\AA$ ): Chemical characterization and emulsifying properties. Food Hydrocolloids, 87, 847-857. doi: https://doi.org/10.1016/ j.foodhyd.2018.09.018 
[18] Ilyukha, N. G., Barsova, Z. V., Kovalenko, V. A., Tsikhanovskaya, I. V. (2010). Production technology and quality indices of a food additive based on magnetite. Eastern-European Journal of Enterprise Technologies, 6 (10 (48)), 32-35. Available at: http://journals.uran.ua/eejet/article/view/5847/5271

[19] Tsykhanovska, I., Evlash, V., Alexandrov, A., Lazarieva, T., Svidlo, K., Gontar, T. et. al. (2018). Substantiation of the mechanism of interaction between biopolymers of ryeandwheat flour and the nanoparticles of the magnetofood food additive in order to improve moistureretaining capacity of dough. Eastern-European Journal of Enterprise Technologies, 2 (11 (92)), 70-80. doi: https://doi.org/10.15587/17294061.2018.126358

[20] Tsykhanovska, I., Evlash, V., Alexandrov, A., Lazarieva, T., Bryzytska, O. (2018). Substantiation of the interaction mechanism between the lipo- and glucoproteids of rye-wheat flour and nanoparticles of the food additive «Magnetofood». Eastern-European Journal of Enterprise Technologies, 4 (11 (94)), 61-68. doi: https://doi.org/10.15587/1729-4061.2018.140048

[21] Zdobnov, A. I., Cyganenko, V. A. (2009). Sbornik receptur blyud i kulinarnyh izdeliy: dlya predpriyatiy obshchestvennogo pitaniya. Kyiv: OOO «Izdatel'stvo Ariy»; Moscow: «Lada», 680.

[22] Arkhipov, V. V., Ivannykova, T. V., Arkhipova, A. V. (2007). Restoranna sprava: Asortyment, tekhnolohiya i upravlinnia yakistiu produktsiyi v suchasnomu restorani. Kyiv: Firma «IIKOS», Tsentr navchalnoi literatury, 382.

[23] Kafka, B. V., Lur'e, I. S. (1988). Tehnologicheskiy kontrol' konditerskogo proizvodstva. Moscow: Pishhevaja Promyshlennost', 207-208.

[24] GOST 5902-80. Metody opredeleniya stepeni izmel'cheniya i plotnosti poristyh izdeliy (2004). Moscow: IPK Izdatel'stvo standartov, 6.

[25] Reotest: instrukciya po ekspluatacii (1978). GDR.

[26] Kosoy, V. D., Vinogradov, Ya. I., Malyshev, A. D. (2005). Inzhenernaya reologiya biotekhnologicheskih sred. Sankt-Peterburg: GIORD, 648.

[27] Zolotareva, L. A., Avetisyan, K. V. (2007). Strukturoobrazovateli i prochnostnye svoystva zheleynyh izdeliy. Khlibopekarska i kondyterska promyslovist Ukrainy, 4, 40-41.

[28] Zakharchuk, V. H., Kundilovska, T. A., Haidukovych, H. Ye. (2016). Tekhnolohiya produktsiyi restorannoho hospodarstva. Odessa: ONEU, Atlant VOI SOIU, 479.

[29] GOST 31986-2012. Uslugi obshhestvennogo pitaniya. Metod organolepticheskoy ocenki kachestva produkcii obshhestvennogo pitaniya (2014). Moscow: Standartinform, 15. 